\title{
A MORPHOLOGICAL PROTOCOL AND GUIDE-LIST ON UTERINE CERVIX CYTOLOGY ASSOCIATED TO PAPILLOMAVIRUS INFECTION
}

\author{
Luzia Setuko Umeda YAMAMOTO(1), Venâncio Avancini Ferreira ALVES(2), Marina Yoshiê Sakamoto MAEDA(1), Adhemar LONGATTO-FILHO(1),
} Maria Lucia UTAGAWA(1) \& José ELUF NETO(3)

\begin{abstract}
SUMMARY
The present study was designed to further assess the validity of the cytological description of morphological lesions said to be related to Papillomavirus (HPV) infections in senior women. The casuistic comprised 196 cervical smears from a group of women with no clinical or morphological evidence of neoplasia, collected simultaneously with samples submitted to detection of HPV DNA by PCR in a previous study. Three experienced cytologists studied each slide in two different conditions, with an interval of 20 months between them. The first approach was performed under routine laboratory standards, whereas the second was guided by a list of 16 well-defined parameters indicative of HPV-related cytological lesions. When suspicious cases of HPV-related alterations were grouped with positive cases, they showed on average: sensitivity of $25.5 \%$, specificity of $84.4 \%$ and positive predictive value (PPV) of $26.8 \%$. When suspicious cases were grouped with negative cases, sensitivity decreased, whereas specificity and PPV increased, as expected. In the second reading, which followed a "guide-list", a decrease in sensitivity was observed, contrasting with a sharp increase of positive predictive value. Among the 16 cytomorphological criteria tested, "koilocytosis", "mild koilocytosis" and "condylomatous parabasal cells" yielded the best predictive value for HPV DNA detection by PCR. In conclusion, despite the low sensitivity, cytopathologic assessment of cervico-vaginal smears leads to a highly specific diagnosis of HPV infection in menopausal women, with PPV of $91.0 \%$ when directed by a guide-list of well-defined morphologic criteria.
\end{abstract}

KEYWORDS: HPV infection; PCR; Cervical smears; Cytomorphology.

\section{INTRODUCTION}

The morphological analysis of cervicovaginal cells by the Papanicolaou method is widely accepted as an effective screening test for cervical neoplasia. More recently, it has also been frequently employed to detect morphological changes related to human papillomavirus (HPV) infection ${ }^{2,8}$. The causal relation between certain types of HPV, called "high-risk" types, and cervical cancer was established by several epidemiological and laboratorial studies ${ }^{5,19,24}$. Non-productive (latent) infection by HPV is defined when viral replication only occurs in synchrony with the cellular cycle in normal squamous epithelium, and when the cytopathic effects related to HPV are not detected cytohistologically ${ }^{19}$. The expression of the E4 viral protein in squamous epithelial cells, which produces a collapse in the cytokeratin matrix, possibly leads to the typical perinuclear cavitation, which is one of the features of either clinic or sub-clinic ${ }^{2} \mathrm{HPV}$ productive infection. On the other hand, the nuclear atypia related to HPV is due to the heteroploidy that appears as a result of fusiform mitotic abnormalities, which lead to the replication of the DNA without cytokinesis 7 . The results of these interferences on the mitotic process are the formation of binucleate or multinucleate cells and larger atypical nuclei, followed by heteroploidy ${ }^{19}$.
Sequences of viral genome, detected by molecular hybridization techniques, can remain in the host cell under episomal form or integrated to the DNA. Nuclear changes seem to be more frequent in samples in which integration of HPV DNA has occurred ${ }^{9,15}$. When the Polymerase Chain Reaction (PCR) technique (which detects productive and nonproductive infection in normal cervical epithelial scrapes) is used, the frequency of infection by HPV in general population of sexually active women varies from 15 to $20 \%{ }^{5,24}$. Studies involving postmenopausal women are scanty, and the morphological alterations provoked by the HPV infection in the squamous cells are controversial. JOVANOVIC et al. $(1995)^{10}$ reported the pseudo-koilocytic alterations in postmenopausal women, focusing on the possibility of false positive low-grade diagnosis under certain circumstances. The HPV detection in postmenopausal women is around $10 \%^{29}$.

AYRE (1949) ${ }^{1}$ and PAPANICOLAOU (1954) ${ }^{22}$ were the first to document cytomorphological features which, later on, would be associated with HPV. KOSS \& DURFEE (1956) ${ }^{11}$ defined "koilocytotic atypia" as the presence of enlarged epithelial cells with irregular, hyperchromatic nuclei, encircled by transparent and clear space, from which the term "koilocytosis" derived. Infection by HPV is believed to 


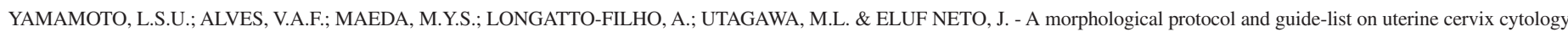
associated to papillomavirus infection. Rev. Inst. Med. trop. S. Paulo, 46(4):189-193, 2004.

originate in the basal layer. After the replication of viral DNA in proliferative basal cells, the virus could, then, infect adjacent epithelial cells. Although the precise morphogenesis of lesions associated with HPV infection is not fully understood, possible cytophatic effects and organizational changes ascribed to HPV include: perinuclear cavity, binucleation, abnormal cytoplasmic keratinization, nuclear atypia and several degrees of nuclear degeneration ${ }^{15,19}$. Recognition of these changes is subordinated to the quality of Pap smears collected, processing, triage and interpretation of microscopic images ${ }^{16}$.

New cervical cancer screening strategies, such as cytology plus HPV DNA testing for women with cervical cytologic abnormalities, have been proposed $^{17,21}$. Our findings may contribute for the improvement of these strategies. The importance of studying this group is evident. Therefore, the aim of this study is to re-assess the value of cervical cytology to identify HPV infection in women who had previously undergone triage with cytological exam "negative for neoplasia", comparing the performance under routine laboratorial conditions to the one directed by a pre-established guide-list of cytomorphological parameters. The presence of HPV DNA detected by PCR was considered the "gold standard".

\section{MATERIALS AND METHODS}

Study population: The present investigation was carried out in cervicovaginal samples from women concomitantly submitted to a cytopathologic study and to an investigation of HPV DNA by PCR. These women were selected as controls in a case-control study conducted in São Paulo City, Brazil, to investigate risk factors for invasive cervical cancer ${ }^{5}$. Women between 18 and 79 years old (mean, 52; median, 51) were invited to participate, recruited from outpatient clinics and in-patient wards of five public hospitals in São Paulo City. The participants of the study had a pelvic examination performed by a gynecologist while exfoliated cells for cytological examination and for HPV analysis were collected.

Of the 225 controls of the previous study, 29 were excluded in the present study: 10 had no cytology taken, or the samples were considered unsatisfactory for interpretation; in 19 controls, the $\beta$-globin gene was not amplified, indicating that the DNA was inadequate for analysis by PCR. Remained, therefore, 196 women who had had cytological exam and PCR performed; 34 (17.3\%) were positive for HPV DNA.

Cytological analysis: Three observers from the Institute Adolfo Lutz, the Central Public Health Laboratory of São Paulo State Health Secretariat, independently reviewed the original slides previously classified as "negative for neoplasia".

Cytological interpretation comprised two reading stages. The first reading reproduced routine laboratorial conditions, conforming to the classification of the Brazilian Ministry of Health (1993) ${ }^{18}$ and the World Health Organization (WHO, 1994) ${ }^{27}$. Twenty months after the first reading, the same three observers performed a guided reading, following a pre-established guide-list with 16 cytomorphological parameters associated with infection by HPV, comprising "classic"13 and "non classic" parameters ${ }^{4,12,14,20,23,25,28,30}$ as listed (Table 1). Observers were not informed that they had previously analyzed those slides. In the first reading, 196 samples were evaluated; in the second reading, due to operational problems, 194 samples were evaluated.
Table 1

HPV "cytomorphological markers" used in the present study

\begin{tabular}{ll}
\hline Marker & Defined by \\
\hline Bi or multinucleation & Naib \& Masukawa, 1961; Meisels \\
& \& Fortin, 1976; Schneider et al., \\
& 1987 \\
& Naib \& Masukawa, 1961; \\
Karyorrhexis & Takahashi, 1982 \\
& Schneider et al., 1987 \\
Cleared cytoplasm & Schneider et al., 1987 \\
Spindle cells & De Borges et al., 1989; Luzzatto et \\
Multinucleated giant cells & al.,1990 \\
& Meisels et al., 1988 \\
Condylomatous parabasal cells & Koss \& Durfee, 1956; Meisels \& \\
Koilocytosis * & Fortin, 1976 \\
& Schneider et al., 1987 \\
Mild koilocytosis & Schneider et al., 1987 \\
Condensation of filaments & Meisels \& Fortin, 1976; Purola \& \\
Dyskeratocytes* & Savia, 1977 \\
& Schneider et al., 1987 \\
Mild dyskeratosis & Naib \& Masukawa, 1961; Meisels \\
Perinuclear halos & \& Fortin, 1976; Schneider et al., \\
& 1987 \\
Nuclear hyperchromatism & Meisels \& Fortin, 1976; Schneider \\
& et al., 1987 \\
Keratohyalin and keratohyalin- & Schneider et al., 1987 \\
like granules & Meisels et al., 1988 \\
Smudge chromatin & Shroyer et al., 1990 \\
Spindle nuclei &
\end{tabular}

* "classic parameters"

Only in the second reading, observers filled in a specific form with all cytological findings. At the end of the form, the exam was classified as positive, negative or suspicious for HPV infection. Observers were not aware of HPV DNA investigation by PCR.

Statistical analysis: Results of HPV DNA investigation by PCR performed at the Department of Pathology, Free University Hospital of Amsterdam 5 , were considered reference (gold standard) to the presence or absence of infection by HPV. To evaluate the cytological exam performance, sensitivity, specificity and positive predictive value (PPV) of the cytomorphological features associated with HPV were calculated with the respective $95 \%$ confidence interval (95\% CI), using the Epi Info software ${ }^{3}$.

In order to assess the validity of the classification "suspicious for HPV", cases classified as such were analyzed twice: grouped together with the "positive for HPV" cases, and grouped with the "negative" cases.

\section{RESULTS}

First reading: Of the 196 samples, ten $(5.1 \%)$ were considered inadequate by at least one observer and were excluded from the analysis. All the 34 positive samples for HPV DNA by PCR were among the 186 valid ones. In the first cytological reading of these 34 samples, under routine conditions, six (by observer A), two (by observer B) and three 


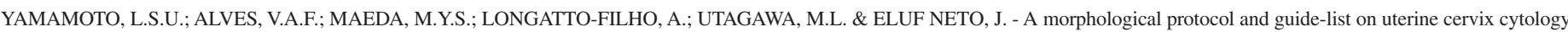
associated to papillomavirus infection. Rev. Inst. Med. trop. S. Paulo, 46(4):189-193, 2004.

(by observer C) were considered positive for HPV. Three, seven and five samples were classified as "suspicious for HPV" by observers A, B and $\mathrm{C}$, respectively.

Among the 152 HPV DNA negative samples, 12 were considered positive by observer A, two by observer B and three by observer C. The three observers considered 26, 14 and 14 samples "suspicious", respectively.

In Table 2, suspicious cases were grouped with positive ones. Such analysis showed on average: sensitivity of $26 \%$, specificity of $84 \%$, positive predictive value (PPV) of $27 \%$. When suspicious cases were grouped with negative ones, as expected, sensitivity decreased, whereas specificity and PPV increased (Table 3).

Second reading: Of the 194 samples analyzed by the same three observers in the second reading, $16(8.2 \%)$ were considered inadequate by at least one observer, remaining 178 valid samples. Since one of the inadequate samples corresponded to a woman diagnosed as infected by HPV by the PCR technique, 33 positive samples remained for the second reading.

The 33 positive cytological samples for HPV DNA by PCR were evaluated by the observers as follows: observer A - four positive and four suspicious for HPV; observer B - four positive and five suspicious; observer $\mathrm{C}$ - two positive and one suspicious.

In the evaluation of the 145 negative samples for HPV by the PCR technique, observer A considered one sample positive and three suspicious; observer B considered 16 samples suspicious, and observer $\mathrm{C}$ considered four samples suspicious. None of these samples were considered positive by observers $\mathrm{B}$ and $\mathrm{C}$.

Overall, the performance of the cytological test was sharply improved comparing with the first reading. Such improvement was observed in both analyses - by grouping suspicious samples with either positive (Table 2 ) or negative ones (Table 3). Despite a small decrease in sensitivity, the second reading produced a large improvement in PPV. When the suspicious cases were grouped with those negative, PPV increased from $39 \%$ to $91 \%$ (Table 3 ).

Among the 16 cytomorphological parameters, "koilocytosis" presented the best PPV (mean 42\%), followed by "mild koilocytosis" (mean 31\%) and "condylomatous parabasal cells" (mean 28\%) (Fig. 1).

Table 2

Performance of cytologic evaluation for HPV - associated lesions on routine laboratory conditions (first reading) and following a guide-list (second reading), including the "suspicious" cases among those "positive for HPV"

\begin{tabular}{|c|c|c|c|c|}
\hline \multirow[b]{2}{*}{$\begin{array}{l}\text { Observers } \\
(\mathrm{A}, \mathrm{B}, \mathrm{C})\end{array}$} & \multicolumn{2}{|c|}{ First reading } & \multicolumn{2}{|c|}{ Second reading } \\
\hline & $\begin{array}{l}\text { Mean } \\
(\%)\end{array}$ & $(95 \% \mathrm{CI})^{* *}$ & $\begin{array}{l}\text { Mean } \\
(\%)\end{array}$ & $(95 \% \mathrm{CI})^{* *}$ \\
\hline Sensitivity & 25.5 & $(12.7-44.0)$ & 20.2 & $(8.9-38.6)$ \\
\hline Specificity & 84.4 & $(77.5-89.6)$ & 94.5 & $(89.4-97.6)$ \\
\hline $\mathrm{PPV} *$ & 26.8 & $(13.4-45.9)$ & 45.5 & $(21.3-73.4)$ \\
\hline
\end{tabular}

*PPV Positive predictive value; $* * 95 \%$ Confidence Interval
Table 3

Performance of cytologic evaluation for HPV - associated lesions on routine laboratory conditions (first reading) and following a guide-list (second reading), including the "suspicious" cases among those "negative for HPV"

\begin{tabular}{|c|c|c|c|c|}
\hline \multirow[b]{2}{*}{$\begin{array}{l}\text { Observers } \\
(\mathrm{A}, \mathrm{B}, \mathrm{C})\end{array}$} & \multicolumn{2}{|c|}{ First reading } & \multicolumn{2}{|c|}{ Second reading } \\
\hline & $\begin{array}{l}\text { Mean } \\
(\%)\end{array}$ & $(95 \% \mathrm{CI})^{* *}$ & $\begin{array}{l}\text { Mean } \\
(\%)\end{array}$ & $(95 \% \mathrm{CI})^{* *}$ \\
\hline Sensitivity & 10.8 & $(3.3-7.2)$ & 10.1 & $(3.3-27.7)$ \\
\hline Specificity & 96.3 & $(91.6-98.5)$ & 99.8 & $(96.2-100)$ \\
\hline PPV * & 39.3 & $(12.6-75.4)$ & 91 & $(22.5-100)$ \\
\hline
\end{tabular}

*PPV Positive predictive value; $* * 95 \%$ Confidence Interval

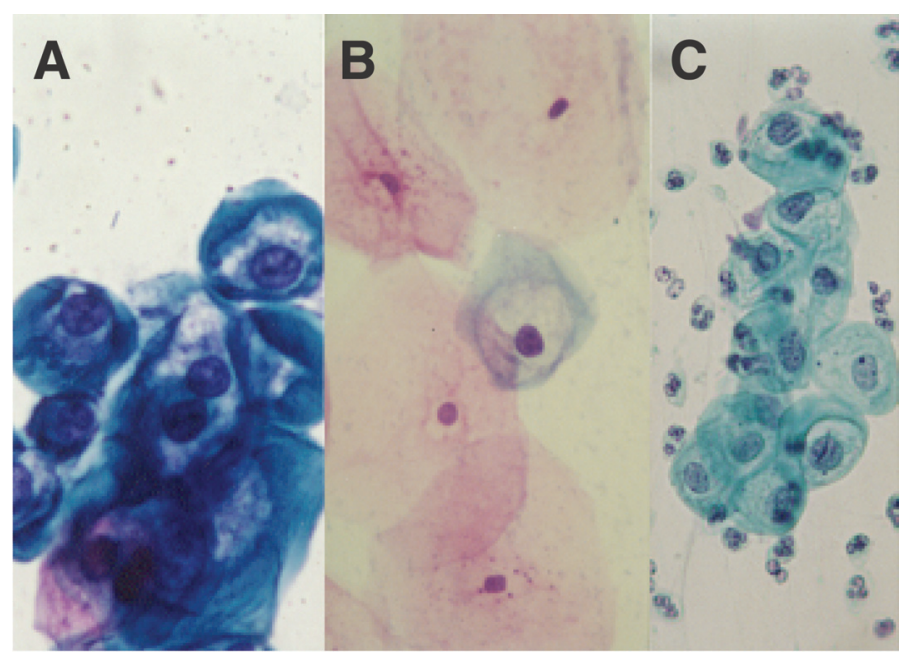

Fig. 1 - The three "individual cytomorphological criteria" which presented the best predictive value in the diagnosis of HPV infection: A - Koilocytosis (Papanicolaou stain, x 400). B Mild koilocytosis (Papanicolaou stain, x 400). C - Condylomatous parabasal cells (Papanicolaou stain, $\mathrm{x}$ 400).

\section{DISCUSSION}

In the present study, we assessed the value of cytology for the identification of HPV infection in a population of older women with cervical smears previously considered negative for neoplasia. These women participated as controls in a case-control study carried out in São Paulo City 5 .

Koilocytotic atypia defined by KOSS \& DURFEE in $1956^{11}$, and associated with HPV infection by MEISELS \& FORTIN, $1976^{13}$, has been the most reliable indicative of cytomorphological lesions related to HPV. Nonetheless, during the last decade, because of the demonstration of a relatively low sensitivity of cytology to identify this viral infection, several "non classic" parameters have been suggested, resulting in a considerable loss of specificity ${ }^{12,14,25}$.

In the present study, in a casuistic of relatively old women, cervical cytology presented low sensitivity and high specificity for the identification of HPV infection detected by PCR. GJ $\varnothing \mathrm{EN}$ et al. obtained similar results in women without cervical dysplasia, aged between 20 and 44: sensitivity of $26 \%$ and specificity of $95 \%$. 


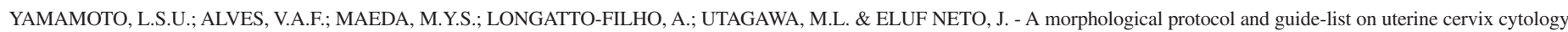
associated to papillomavirus infection. Rev. Inst. Med. trop. S. Paulo, 46(4):189-193, 2004.

In the present investigation, sensitivity remained low, independently of either the way of grouping the women with results considered "suspicious for infection by HPV", or the kind of reading (routine or guided) performed. However, specificity was higher when women with samples considered "suspicious" were grouped with those considered negative, and the reading was performed following a parameter guidelist. The greatest (and most important) difference between routine and guided readings was found in the positive predictive value, especially when "suspicious" samples were grouped with negative ones.

Considered the most sensitive method of detection of HPV infections, PCR detects productive as well as nonproductive infections. Many women with an HPV positive sample by PCR might be in a "nonproductive" stage, which explains the low sensitivity of cervical cytology. The interpretation of the cytomorphological features associated with HPV in Pap smears from postmenopausal women can be even more difficult. Since HPV needs epithelial differentiation to complete the development cycle, low levels of circulating estrogen reduce the maturation of squamous cervical cells ${ }^{6,8,15,26}$. The high proportion of postmenopausal women may have also contributed to the low sensitivity found in this study.

The results obtained herein demonstrate that the reading following a parameter guide-list conducted to a marked improvement of the positive predictive value. They also show the inadequacy of using the terminology "suspicious changes of viral infection". The sensitivity gains of such practice are of little significance, while reduction of specificity can bring undesirable worries to the patient and, occasionally, leading to inadequate therapeutic actions.

\section{RESUMO}

\section{Padronização da análise de critérios citomorfológicos de lesões associadas à infecção pelo HPV}

O presente estudo analisou aspectos relacionados ao valor da citologia cervical na identificação de alterações cito-morfológicas relacionadas à infecção por Papilomavírus humano (HPV) em mulheres com idades avançadas. A casuística compreendeu 196 amostras cérvico-vaginais provenientes de uma população de mulheres sem evidências clínicas ou citológicas de neoplasia cervical. As amostras foram coletadas simultaneamente para pesquisas para DNA-HPV por Reação de Polimerização em Cadeia (PCR) e citologia. Três observadores experientes efetuaram análise das lâminas em duas etapas com intervalo de 20 meses: a primeira em condições de rotina laboratorial e a segunda dirigida por um roteiro de critérios pré-estabelecidos. Quando os casos suspeitos para alterações relacionadas ao HPV foram agrupados com os casos positivos, eles mostraram em média: $25,5 \%$ de sensibilidade, $84,4 \%$ de especificidade e valor preditivo positivo (VPP) de 26,8\%. Quando os casos suspeitos foram agrupados com os negativos, a sensibilidade diminuiu, e a especificidade e o VPP aumentaram. Na segunda leitura, a sensibilidade diminuiu, contrastando com o aumento do VPP. Entre os 16 critérios cito-morfológicos avaliados, coilocitose, coilocitose leve e célula parabasal coilocitótica foram os que apresentaram melhor VPP para HPV em comparação ao PCR. Concluímos que, apesar da baixa sensibilidade, o painel de critérios cito-morfológicos poderá elevar a especificidade do teste de Papanicolaou para triagem das alterações relacionadas à infecção por HPV em pacientes de mais idade.

\section{REFERENCES}

1. AYRE, J.E. - The vaginal smear: "pre-cancer" cell studies using a modified technique. Amer. J. Obstet. Gynec., 53: 609-617, 1949.

2. CRITCHLOW, C.W. \& KOUTSKY, L.A. - Epidemiology of human papillomavirus infection. In: MINDEL, A. Genital warts: human papillomavirus infection. London, Edward Arnold, 1995. p. 53-81.

3. DEAN, A.G.; DEAN, J.A.; COULOMBIER, D. et al. - Epi Info Version 6. Atlanta, CDCP, 1995.

4. DE BORGES, R.J.; GARCIA-TAMAYO, J. \& ZAITZMAN, M. - Cytologic and ultrastructural findings of a peculiar alteration in cervical cells from patients with human papillomavirus infections. Acta cytol., 33: 314-318, 1989.

5. ELUF-NETO, J.; BOOTH, M.; MUÑOZ, N. et al. - Human papillomavirus and invasive cervical cancer in Brazil. Brit. J. Cancer, 69: 114-119, 1994.

6. FRANCO, E.L. \& FERENCZY, A. - Assessing gains in diagnostic utility when human papillomavirus testing is used as an adjunct to Papanicolaou smear in the triage of women with cervical cytologic abnormalities. Amer. J. Obstet. Gynec., 181: 382 386, 1999.

7. FU, Y.S.; REAGAN, J. \& RICHART, R.M. - Definition of precursors. Gynec. Oncol., 12: $\mathrm{S} 220-\mathrm{S} 231,1981$.

8. GJ $\varnothing E N$, K.; SAUER, T.; OLSEN, A.O.; ØRSTAVIK, I. - Correlation between polymerase chain reaction and cervical cytology for detection of human papillomavirus infection in women with and without dysplasia. Acta path. microbiol. immunol. scand., 105: 71-75, 1997.

9. GUPTA, P.K. - Microbiology, inflammation and viral infections. In: BIBBO, M. Comprehensive cytopathology. Philadelphia, Saunders, 1997. p. 125-160.

10. JOVANOVIC, A.S.; McLACHLIN, M.; SHEN, L.; WELCH, W.R. \& CRUM, C.P. Postmenopausal squamous atypia: a spectrum including "pseudo-koilocytosis". Mod. Path., 8: 408-412, 1995.

11. KOSS, L.G. \& DURFEE, G.R. - Unusual patterns of squamous epithelium of the uterine cervix: cytologic and pathologic study of koilocytotic atypia. Ann. N. Y. Acad. Sci., 63: $1245-1261,1956$

12. LUZZATTO, R.; RECKTENVALD, M. \& PORTUGAL, J.PL. - Multinucleation and abortive cellular division in human papillomavirus infection. Acta cytol., 34: 286$287,1990$.

13. MEISELS, A. \& FORTIN, R. - Condylomatous lesions of the cervix and vagina. I. Cytologic patterns. Acta cytol., 20: 505-509, 1976.

14. MEISELS, A.; MORIN, C.; CASAS-CORDERO, M.; ROY, M. \& FORTIER, M. Condyloma of the uterine cervix. In: International Academy of Cytology. Compendium on Diagnostic Cytology. Tutorials of Cytology. 6. ed. Chicago, 1988. p. 63-88.

15. MEISELS, A. \& MORIN, C. - The human papillomaviruses and cancer of the uterine cervix: cytopathology of the uterus. 2. ed. Chicago, AJCP Press, 1997. p. 185-226.

16. MELAMED, M.R. - Quality control in cytology laboratories. Gynec. Oncol., 12: S206S211, 1981.

17. MILD-LANGOSCH, K.; RIETHDORF, S.; LÖNING, T. - Association of human papillomavirus infection with carcinoma of the cervix uteri and its precursor lesions: theoretical and practical implications. Virchows Arch., 437: 227-233, 2000.

18. MINISTÉRIO DA SAÚDE DO BRASIL - Seminário Nacional sobre Nomenclatura e Controle de Qualidade dos Exames Citológicos e Prevenção do Câncer Cérvicouterino. Rio de Janeiro, 1993. 
19. MONOGRAPHS on the Evaluation of Carcinogenic risk to Humans. Human Papillomaviruses. Lyon, International Agency for Research on Cancer (IARC), 1995. v. 64 , p. $82-231$

20. NAIB, Z.M. \& MASUKAWA, N. - Identification of condyloma acuminata cells in routine vaginal smears. Obstet. Gynec., 18: 735-738, 1961.

21. NOBBENHUIS, M.A.E.; WALBOOMERS, J.M.M.; HELMERHORS, T.J.M. et al. Relation of human papillomavirus status to cervical lesions and consequences for cervical-cancer screening: a prospective study. Lancet, 354: 20-25, 1999.

22. PAPANICOLAOU, G.N. - Atlas of exfoliative cytology. Cambridge, Harvard University Press, 1954

23. PUROLA, E. \& SAVIA, E. - Cytology of gynecologic condyloma acuminatum. Acta cytol., 21: 26-31, 1977.

24. SCHIFFMAN, M.; BAUER, H.; HOOVER, R. et al. - Epidemiologic evidence showing that human papillomavirus infection causes most cervical intraepithelial neoplasia. J. nat. Cancer Inst., 85: 958-964, 1993

25. SCHNEIDER, A.; MEINHARDT, G.; DE VILLIERS, E.M. \& GISSMANN, L. Sensitivity of the cytologic diagnosis of cervical condyloma in comparison with HPVDNA hybridization studies. Diagn. Cytopath., 3: 250-255, 1987.
26. SCHNEIDER, A. \& KOUTSKY, L.A. - Natural history and epidemiological features of genital HPV infection. In: MUÑOZ, N.; BOSCH, F.X.; SHAH, K.V. \& MECHEUS, A. The epidemiology of human papillomavirus and cervical cancer. Lyon, International Agency for Research on Cancer, 1992. p. 25-52. (IARC Scientific Publication 119).

27. SCULLY, R.E.; BONFIGLIO, T.A.; KURMAN, R.J.; SILVERBERG, S.G. \& WILKINSON, E.J. - WHO International Histological Classification of Tumor Histological typing of female genital tract tumours. 2. ed. Geneva, Springer Verlag, 1994.

28. SHROYER, K.R.; HOSEY, J.; SWANSON, L.E; WOODARD, W.D. \& FENNELL, R.H - Cytologic diagnosis of human papillomavirus infection: spindled nuclei. Diagn. Cytopath., 6: 178-183, 1990

29. SYMMANS, F.; MECHANIC, L.; MACCONNEL, P. et al. - Correlation of cervical cytology and human papillomavirus DNA detection in postmenopausal women. Int. J. gynec. Path., 11: 204-209, 1992

30. TAKAHASHI, M. - Atlas colorido de citologia do câncer. São Paulo, Manole, 1982 p. $48-49$.

Received: 4 May 2004

Accepted: 5 July 2004 